\title{
Biotransformation of fruit residues via solid state bioprocess using Lichtheimia ramosa
}

\author{
Cinthia Aparecida de Andrade Silva ${ }^{1}$ Pedro Garcia Pereira da Silva ${ }^{1}$. Gisele Fernanda Alves da Silva ${ }^{1}$. \\ Dábila Pereira Dantas ${ }^{1} \cdot$ Rodrigo Simões Ribeiro Leite $^{2} \cdot$ Gustavo Graciano Fonseca $^{1}$ (I)
}

Received: 19 September 2019 / Accepted: 4 April 2020 / Published online: 9 April 2020

(c) Springer Nature Switzerland AG 2020

\begin{abstract}
Lichtheimia ramosa is a promising candidate fungus for solid state bioprocesses (SSB) due its rapid colonization. Fruit wastes present ideal conditions for fungal growth and biotransformation, which can promote the release of products of biotechnological interest. Thus, the aim of this work was to evaluate the mycelial growth and the enzymatic activities of L. ramosa in pineapple (Ananas comosus), orange (Citrus sinensis), mango (Mangifera indica), passion fruit (Passiflora edulis) and grape (Vitis vinifera) fruit wastes via SSB, and their influence in the generation of molecules with potential use. The SSB was evaluated in terms of capacity of biotransformation of the substrate (composition, protein enrichment, and fatty acid profile) and production of amylase, carboxymethylcellulase (CMCase), xylanase and lipase enzymes. Main cultivations were carried out at $30^{\circ} \mathrm{C}$ for 30 days and every 5 days samples were taken and analyzed for microbiological content, proximal composition and enzymatic profile. Fatty acids were determined at day 0 (baseline) and at the end of the cultivations. L. ramosa grew well in all substrates up to the 25th day, except for on the orange residue, upon which development was slightly lower at this time. Protein enrichment was found in all substrates as follows: passion fruit (309.54\%), pineapple (294.89\%), mango (263.45\%), orange (65.60\%) and grapes (19.17\%). Regarding enzymes, lipase was not synthetized in any of the substrates, though amylase, CMCase and xylanase were observed at different levels. The fatty acid profile varied from raw to cultivated substrates, indicating that $L$. ramosa can act in the synthesis and conversion of these acids. It was concluded that $L$. ramosa and the studied substrates are viable for SSB.
\end{abstract}

Keywords Biocatalysis · Biomass · Enzyme · Protein enrichment · Fatty acids · Waste

\section{Introduction}

Solid state bioprocesses (SSB) are versatile and can be used beyond biotransformation of wastes for nutritional enrichment. For example, they are widely used for industrial applications due to their potential to produce several compounds of industrial interest, e.g. enzymes, organic acids, fuels, foods, and biologically active secondary metabolites [1-3].
In SSB, the solid matrix may serve as both the support and nutrient source, allowing microbial growth. The substrate choice is a very important factor for an efficient bioprocess [4]. The use of agricultural residues as substrates provides an alternative for SSB because it adds value to these materials and assists in the mitigation of environmental problems [5]. Fruit wastes are rich in starch, cellulose, soluble sugars and organic compounds [6] and those of interest for SSB include apple, grape, kiwi, orange, pineapple, pequi, and guavira, among others $[4,7-9]$

Gustavo Graciano Fonseca, ggf@ufgd.edu.br|'aboratory of Bioengineering, Faculty of Biological and Environmental Sciences, Federal University of Grande Dourados, Dourados, MS, Brazil. ${ }^{2}$ Laboratory of Enzymology and Fermentation Processes, Faculty of Biological and Environmental Sciences, Federal University of Grande Dourados, Dourados, MS CEP 79804-970, Brazil. 
The utilization of SSB to produce enzymes and protein enrichment has received great attention due to the low level of applied technology and efficiency in the conversion of substrates [4], with several applications widely reported in the literature, as amylase production to be used in the pharmaceutical and food industry, use of carboxymethylcellulase (CMCase), xylanase, and $\beta$-glucosidase have potential to hydrolyze plant cell wall e lipases are very important both from a physiological aspect, since they hydrolyze oils and fats into free fatty acids [9-11].

Among the microorganisms usually employed in SSB are filamentous fungi because they require less moisture, adapt to solid residues as substrates and have hyphae which allow greater penetration into the substrate [4, 8]. Lichtheimia ramosa is a filamentous fungus that belongs to the order Mucorales and class Zygomycetes [12] which exhibit rapid colonization, and are therefore, favorable for solid cultivations.

Lichtheimia ramosa has vigorous mycelial growth up to 30 days of cultivation on substrates with araticum, pequi and guavira fruit residues in SSB $[1,4]$. Furthermore, it was previously reported as a $\beta$-glucosidase, amylase, CMCase and xylanase enzyme producer $[2,5$, $13,14]$ beyond enabling the bioconversion of residual fruit substrates [4]. It was reported elsewhere no deleterious effects from feeding a high moisture, ensiled, moldy shelled corn with L. ramosa and other fungi to lactating dairy cows [15]. However, despite its great biotechnological potential, some clinical cases related to this fungus were described in immunodepressed patients [12].

Thus, the aim of this work was to evaluate the mycelial growth and the enzymatic activities of $L$. ramosa in pineapple (Ananas comosus), orange (Citrus sinensis), mango (Mangifera indica), passion fruit (Passiflora edulis) and grape (Vitis vinifera) fruit wastes via SSB, and their influence in the generation of molecules with potential use. The SSB was evaluated in terms of the capacity for biotransformation of the substrate, including composition and protein enrichment; production of amylase, CMCase, xylanase and lipase enzymes; and fatty acids profile.

\section{Materials and methods}

\subsection{Microorganism}

Lichtheimia ramosa was isolated from sugarcane bagasse in Dourados, MS [14]. The microorganism was maintained on a Sabouraud Dextrose Agar medium and after growth at $28^{\circ} \mathrm{C}$ for $48 \mathrm{~h}$, the strain was stored at $4^{\circ} \mathrm{C}$.

\subsection{Substrates}

Pineapple peel (Ananas comosus, pearl variety), orange skin (Citrus sinensis, pear variety), mango peel (Mangifera indica, Tommy variety), passion fruit peel (Passiflora edulis, yellow passion fruit variety) and grape skin (Vitis vinifera, pink Niagara variety) wastes were utilized as substrates. Fruits were obtained from the local commerce, with the same collection period and mature degree. At the lab, fruits were selected by color intensity (characteristic of each fruit) to obtain fruits with uniform maturity. The selected fruits were then manually peeled and washed 3 times in running tap water to remove impurities and pulp debris. $70 \mathrm{~g}$ of each substrate was conditioned in $500 \mathrm{~mL}$ Erlenmeyer flasks before being autoclaved at $121^{\circ} \mathrm{C}$ for $15 \mathrm{~min}$. Wherever necessary, these substrates had the $\mathrm{pH}$ adjusted to 5.0 with $1 \mathrm{M} \mathrm{HCl}$ and the moisture corrected to $60 \%$ with sterile distilled water. 7 flasks were prepared for each substrate comprised of fruit waste.

\subsection{Inoculum: "Spawn"}

For spawn preparation, wheat grains precooked for 15 min, gypsum and $\mathrm{CaCO}_{3}$ were mixed in the proportions of $98.6 \%, 0.8 \%$ and $0.6 \%$, respectively, as defined in preliminary studies for $\mathrm{pH}$ maintenance. The $\mathrm{pH}$ was adjusted to 5.0 with $1 \mathrm{M} \mathrm{HCl}$ (Vetec) and the initial moisture content set to $50 \%$ with distilled water [13]. $50 \mathrm{~g}$ of the mixture were placed into a $300 \mathrm{~mL}$ Erlenmeyer flask before being autoclaved at $121^{\circ} \mathrm{C}$ for $15 \mathrm{~min}$ [10]. Inoculation of the fungus was carried out by transferring a $1 \mathrm{~cm}^{2}$ square area of mycelium contained in the center of a PDA petri dish to the Erlenmeyer flask with the aid of a previously sterilized and labeled spatula. The petri dish was previously prepared from the preserved microorganism and maintained for a maximum of 1 month at $4{ }^{\circ} \mathrm{C}$.

Subsequently, the flasks were incubated in a bacteriological incubator at $30^{\circ} \mathrm{C}$ for $168 \mathrm{~h}$ to serve as spawns for the main cultivations [9]. Next, $7 \mathrm{~g}$ of the $70 \mathrm{~g}$ total, or $10 \%$ $(\mathrm{w} / \mathrm{w})$ of the total weight of the main culture substratum, was separated with a previously sterilized spatula and aseptically weighed. The $7 \mathrm{~g}$ culture was then distributed into 7 Erlenmeyer flasks $(500 \mathrm{~mL})$ each containing a substrate comprised of fruit waste.

\subsection{Cultivation}

The $500 \mathrm{~mL}$ Erlenmeyer flasks were kept in a bacteriological incubator at $30^{\circ} \mathrm{C}$ for 30 days for mycelial growth. This time was defined based on the growth of the L. ramosa fungus in SSB, as described in the literature [1, 4]. A flask 
inoculated with each substrate was taken every 5 days in order to evaluate the dynamic changes in media during growth, which resulted in 7-point kinetic experiments. Day 0 was set just after inoculation of the medium. Samples were homogenized and used to determine the microbiological content, proximal composition, fatty acid and enzymatic profiles. The cultivations were carried out in duplicate and the analyzes in triplicate.

\subsection{Sampling for microbiological preparation}

For each flask, $25 \mathrm{~g}$ of the homogenized medium was used for microbiological examination. During sampling and preparation, a sterile environment was maintained. The sample was transferred to a stomacher bag and homogenized for $60 \mathrm{~s}$ in a Seward Stomacher ${ }^{\circledast} 400$ Circulator with $225 \mathrm{~g}$ chilled saline peptone diluent comprised of $0.85 \%$ $\mathrm{NaCl}$ with $0.1 \%$ peptone (Himedia). Further appropriate tenfold dilutions of the homogenate were made with saline peptone diluent. For each dilution blank, two replicas were prepared.

\subsection{Determination of Lichtheimia ramosa}

Lichtheimia ramosa was assayed according to classical methodology for fungal determinations as follows: $0.1 \mathrm{~mL}$ from each appropriate dilution step was spread on the surface of potato dextrose agar (PDA) media into Petri dishes, which were incubated in a Biochemical Oxygen Demand (BOD) chamber at $25^{\circ} \mathrm{C}$ for $120 \mathrm{~h}$ before the colonies were counted $[16,17]$. Growth was expressed in terms of microbial population (CFU/g) during cultivation. The maximum specific growth rate $\left(\mu_{\max }\right)$ was determined as the slope of this linear region in the exponential growth phase [18]. Mesophilic bacteria were determined by using plate counting agar (PCA) in deep $\left(35^{\circ} \mathrm{C}, 48 \mathrm{~h}\right)$ and psychrotrophic bacteria using PCA in surface $\left(7^{\circ} \mathrm{C}, 240 \mathrm{~h}\right)$ [19] to monitor possible contamination during experiments.

\subsection{Proximate composition}

Moisture, crude protein, crude fat, crude fiber and crude ash contents were determined in triplicate according to the methods defined by AOAC [20]. Moisture was determined by the oven-drying method at $105^{\circ} \mathrm{C}$ until constant weight was obtained (method 950.46), protein by the Kjeldhal method using a 6.25 factor to convert the nitrogen content into crude protein (method 928.08), fat by the Soxhlet method (method 960.39), crude fiber content by the gravimetric method using a fiber determiner (method 978.10), and ash by using the muffle-oven technique (method 920.153). Carbohydrates were calculated by difference according to Eq. 1 :
$\% \mathrm{CHO}=10-(\% \mathrm{ASH}+\% \mathrm{LIP}+\% \mathrm{PRO}+\% \mathrm{FIB})$

where $\mathrm{CHO}$, carbohydrates; ASH, ashes; LIP, lipids; PRO, proteins; and FIB, fibers. Results were expressed as $\%$ $(\mathrm{g} / 100 \mathrm{~g})$ by the mean and standard deviation. $\mathrm{CO}_{2}$ production was not considered.

\subsection{Enzyme activity}

\subsubsection{Aqueous enzymatic extraction}

For the enzyme extraction, $50 \mathrm{~mL}$ of distilled water were added to Erlenmeyer flasks containing $5 \mathrm{~g}$ of the cultivated mediums. The microorganisms were placed on an orbital shaker (Marconi, Brazil) at $130 \mathrm{rpm}$ and $35^{\circ} \mathrm{C}$ for $30 \mathrm{~min}$. They were then paper filtered (Whatman, no. 1) and centrifuged at $1232.6 \times g$ for $5 \mathrm{~min}$ (ITR, Brazil), yielding the crude enzyme extract from the supernatant to be used for the determination of enzyme activity [21].

\subsubsection{Amylase, CMCase and xylanase activities}

The activities of amylase, CMCase and xylanase were determined in a solution comprised of $0.1 \mathrm{~mL}$ of the enzyme filtrate, $0.9 \mathrm{~mL}$ of $0.2 \mathrm{M}$ acetate buffer ( $\mathrm{pH} \mathrm{5.0)}$ ) and $1 \%$ substrate (corn starch, carboxymethylcellulose or xylan, respectively) (Sigma). The reaction progressed for $10 \mathrm{~min}$ at $50^{\circ} \mathrm{C}$ before being halted in an ice bath.

These activities were measured by the amount of reducing sugar present in the final enzymatic reaction, quantified by the 3,5-dinitrosalicylic acid method (DNS) [22]. One unit of enzyme activity was defined as the amount of enzyme able to release $1 \mu \mathrm{mol}$ of the respective product per minute of reaction. The results were expressed in terms of units per gram of dry substrate ( $\mathrm{U} / \mathrm{g}$ dry substrate).

\subsubsection{Lipase activity}

To start the reaction for lipase activity analysis, $0.1 \mathrm{~mL}$ of crude enzyme extract was added to $0.9 \mathrm{~mL}$ of substrate solution containing $3 \mathrm{mg}$ of $p$-nitrophenyl palmitate ( $p$ NPP) (Sigma). This was dissolved in $1 \mathrm{~mL}$ of isopropanol and $9 \mathrm{~mL}$ of the following solution: $2 \mathrm{~g}$ of Triton $\mathrm{X}-100$ and $0.5 \mathrm{~g}$ of arabic gum in $450 \mathrm{~mL}$ of $0.05 \mathrm{M}$ phosphate buffer with $\mathrm{pH} 7.0$ [13]. The mixture was incubated in a water bath at $37^{\circ} \mathrm{C}$ for $20 \mathrm{~min}$ and then placed in an ice bath and analyzed in a spectrophotometer at $410 \mathrm{~nm}$. The control solution consisted of $0.1 \mathrm{~mL}$ of inactivated enzyme [23]. One unit of lipase activity was defined as the amount of enzyme able to release $1 \mu \mathrm{mol}$ of product ( $p$-nitrophenol) per minute of reaction. The results were expressed in terms of units per gram of dry substrate ( $\mathrm{U} / \mathrm{g}$ dry substrate). 


\subsection{Fatty acid composition}

The lipid extracts obtained by the cold method [24] were esterified following the guidelines of the ISO 5509 standard [25]. Fatty acid composition was determined at baseline and end of cultivations by preparation of methyl esters.

The fatty acid methyl esters (FAME) were extracted and identified by using gas chromatography coupled to mass spectrometry using a GC-MS Agilent 7890a equipped with a $30 \mathrm{~m} \times 0.25 \mathrm{~mm} \times 0.25 \mathrm{~m}$ HP-5MS capillary column and using helium as entrainment gas at a split ratio of 1:10. The analyses were done starting at $180^{\circ} \mathrm{C}$ and up to $300^{\circ} \mathrm{C}$ at a heating rate of $10^{\circ} \mathrm{C} / \mathrm{min}$. The detector and injector temperatures were $325^{\circ} \mathrm{C}$ and $300^{\circ} \mathrm{C}$, respectively, and the gas chromatographic analysis was performed in duplicate. The FAME were identified by comparing the retention time of the constituents of the sample with a mixture of 19 fatty acid methyl ester standards (FAME mix, Sigma-Aldrich) and by comparison with the mass spectra of the NIST MS Search 2.0 library included in the chromatograph's software. Quantification was performed relative to an internal standard of methyl tricosanoate at 23:0 (Sigma-Aldrich) following the method described elsewhere [26].

\subsection{Protein enrichment (PE)}

Protein enrichment (PE) or protein variation was calculated by the percentage difference between concentration of proteins presented in cultivated medium (higher protein concentration) and treated substratum (after inoculation) according to Eq. 2 [10].

$\mathrm{PE}(\%)=\left(\frac{\text { higher protein content }(\%)}{\text { inicial protein content }(\%)} \times 100\right)-100$

\subsection{Statistical analysis}

Results of proximal composition were subjected to an analysis of variance (ANOVA) at $5 \%$ probability by the Tukey test using Statistica version 6.0 software (Statsoft, USA).

\section{Results and discussion}

\subsection{Microbial growth}

Growth kinetics were carried out for L. ramosa in five different fruit waste substrates as shown in Fig. 1. It was also found that in mango, grape, passion fruit and pineapple

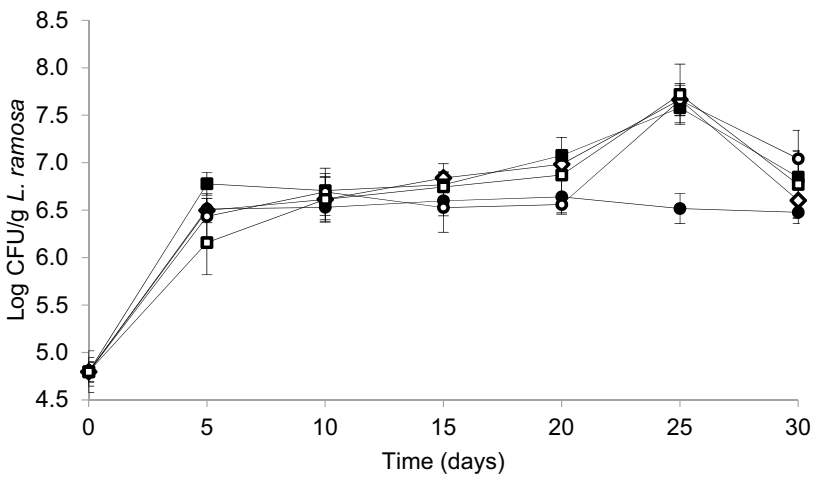

Fig. 1 Growth kinetics of L. ramosa in pineapple (open square), orange (filled circle), passion fruit (open circle), mango (open diamond) and grape (filled square) waste substrates. Analyzes were performed in triplicate

wastes $L$. ramosa cells reached, on average, the maximal count of $7.5 \log \mathrm{CFU} / \mathrm{g}(3.16 \mathrm{~g} / \mathrm{L})$ at the 25 th day of cultivation, whereas for the orange residue the maximal growth was $6.5 \log$ CFU/g $(2.73 \mathrm{~g} / \mathrm{L})$ at the 20th day.

The maximum specific growth rates were quite similar for most of the substrates $\left(0.0328 \pm 0.0009 \mathrm{~h}^{-1}\right.$ for orange, $0.0313 \pm 0.0013 \mathrm{~h}^{-1}$ passion fruit, $0.0326 \pm 0.0010 \mathrm{~h}^{-1}$ for mango), as indicated by the linearity from the first to the fifth day of cultivation. However, slightly inferior and superior values were found for pineapple and grape residues ( $0.0261 \pm 0.0027$ and $0.0380 \pm 0.0010 \mathrm{~h}^{-1}$, respectively).

This reduced growth of $L$. ramosa growth in orange waste is related to the adaptation of the microorganism to that medium and its composition. In this case, a lower consumption of carbohydrates and protein conversion was observed. The orange skin residue acts as carbon source because it is characterized by a cell wall rich in cellulose and hemicellulose and contains a lignin that needs to be broken [27].

In addition, citrus skins are rich in D-limonene, a cyclic terpene characterized by its antimicrobial activity [28] due to it being comprised of a hydrophobic cyclic hydrocarbon that is toxic to cell membranes [29]. The presence of limonene could explain the reduced growth of $L$. ramosa in orange skin waste.

Lichtheimia ramosa is known for its capacity for growing in fruit wastes $[1,4,13]$. For example, its growth was evaluated in hog plum, bocaiuva, pequi, guavira and araticum fruit wastes [1]. The best results for growth were obtained in araticum and pequi wastes on the 25th day of cultivation, which were close to the $7.5 \mathrm{log} C F U / \mathrm{g}(3.16 \mathrm{~g} / \mathrm{L})$ observed here for mango, grape, passion fruit and pineapple wastes and shown in Fig. 1.

Other fungi are recognized by their ability to grow in fruit waste, e.g. Pleurotus sajor-caju in pequi and guavira wastes [9] and Aspergillus niger in lemon bagasse 
[30], indicating that many fruit residues are adequate for microbial development intended for biotechnological applications.

The presence of neither mesophilic nor psychrophilic bacteria were detected, which indicates that there was no contamination of the cultures. This fact indicates that the initial thermal pretreatment of the substrates was effective. It may also be related to the rapid colonization of $L$. ramosa in all studied fruit wastes mainly during the 5 initial days, as shown in Fig. 1.

\subsection{Proximate composition and protein enrichment}

The variations in the proximate composition of the cultivated media during 30 days are shown in Tables 1, 2, 3, 4 and 5 for pineapple, orange, mango, passion fruit and grape wastes, respectively.

The protein content increased for all substrates (Tables 1, 2, 3, 4, 5). The content increased from 4.11 to $16.23 \%$ in pineapple (Table 1), $10.70-17.72 \%$ in orange (Table 2), $3.42-12.43 \%$ in mango (Table 3 ), $5.97-24.45 \%$ in
Table 1 Approximate composition (\%) of pineapple waste substrate inoculated with $L$. ramosa over 30 days
Table 2 Approximate composition (\%) of orange waste substrate inoculated with $L$. ramosa over 30 days

\begin{tabular}{llrrrr}
\hline Time (days) & \multicolumn{1}{l}{ Lipids* } & \multicolumn{1}{l}{ Proteins* } & \multicolumn{1}{l}{ Ash* } & \multicolumn{1}{l}{ Fiber* } & Carbohydrates* \\
\hline 0 & $1.38^{\mathrm{a}} \pm 0.53$ & $4.11^{\mathrm{a}} \pm 0.46$ & $3.16^{\mathrm{a}} \pm 0.01$ & $17.18^{\mathrm{a}} \pm 0.99$ & $73.84^{\mathrm{a}} \pm 1.61$ \\
5 & $1.75^{\mathrm{a}} \pm 0.31$ & $7.54^{\mathrm{b}} \pm 0.27$ & $4.62^{\mathrm{a}, \mathrm{b}} \pm 0.42$ & $26.34^{\mathrm{b}} \pm 0.47$ & $59.73^{\mathrm{b}} \pm 3.96$ \\
10 & $1.72^{\mathrm{a}} \pm 0.53$ & $8.16^{\mathrm{b}, \mathrm{c}} \pm 0.24$ & $5.59^{\mathrm{a}, \mathrm{b}} \pm 0.29$ & $31.81^{\mathrm{c}} \pm 0.84$ & $53.17^{\mathrm{b}} \pm 1.65$ \\
15 & $1.78^{\mathrm{a}} \pm 0.11$ & $10.48^{\mathrm{b}, \mathrm{c}} \pm 0.81$ & $7.22^{\mathrm{b}} \pm 0.55$ & $36.85^{\mathrm{e}} \pm 0.27$ & $43.69^{\mathrm{c}} \pm 1.03$ \\
20 & $3.58^{\mathrm{a}} \pm 0.10$ & $11.31^{\mathrm{c}, \mathrm{d}} \pm 0.38$ & $6.26^{\mathrm{b}} \pm 0.22$ & $35.66^{\mathrm{d}, \mathrm{e}} \pm 0.55$ & $43.03^{\mathrm{c}} \pm 1.66$ \\
25 & $3.29^{\mathrm{a}} \pm 0.37$ & $14.19^{\mathrm{d}} \pm 0.19$ & $5.43^{\mathrm{a}, \mathrm{b}} \pm 0.38$ & $32.43^{\mathrm{c}, \mathrm{d}} \pm 0.72$ & $43.63^{\mathrm{c}} \pm 2.54$ \\
30 & $3.13^{\mathrm{a}} \pm 0.14$ & $16.23^{\mathrm{e}} \pm 0.38$ & $7.25^{\mathrm{b}} \pm 0.06$ & $29.77^{\mathrm{b}, \mathrm{c}} \pm 0.64$ & $43.43^{\mathrm{c}} \pm 0.71$ \\
\hline
\end{tabular}

Calculated on dry matter basis. Determinations were performed in triplicate

Different letters within the same column indicate significant differences $(P<0.05)$

*Data presented as mean \pm standard deviation of triplicates

\begin{tabular}{lrrrrr}
\hline Time (days) & \multicolumn{1}{l}{ Lipids* } & \multicolumn{1}{l}{ Proteins* } & \multicolumn{1}{l}{ Ash* } & \multicolumn{1}{l}{ Fiber $^{*}$} & Carbohydrates* \\
\hline 0 & $1.21^{\mathrm{a}} \pm 0.26$ & $10.70^{\mathrm{a}} \pm 0.15$ & $3.82^{\mathrm{a}} \pm 0.20$ & $21.63^{\mathrm{a}, \mathrm{c}} \pm 0.51$ & $63.06^{\mathrm{a}} \pm 3.08$ \\
5 & $4.28^{\mathrm{b}} \pm 0.92$ & $10.37^{\mathrm{a}} \pm 0.05$ & $4.98^{\mathrm{a}} \pm 0.16$ & $30.44^{\mathrm{b}} \pm 0.59$ & $49.72^{\mathrm{a}} \pm 3.86$ \\
10 & $6.48^{\mathrm{b}} \pm 0.03$ & $10.74^{\mathrm{a}} \pm 0.22$ & $5.74^{\mathrm{a}, \mathrm{b}} \pm 0.38$ & $20.62^{\mathrm{a}, \mathrm{c}, \mathrm{d}} \pm 0.88$ & $56.51^{\mathrm{a}} \pm 2.69$ \\
15 & $4.42^{\mathrm{b}} \pm 0.85$ & $10.46^{\mathrm{a}} \pm 0.19$ & $7.13^{\mathrm{b}, \mathrm{c}} \pm 0.59$ & $25.96^{\mathrm{a}, \mathrm{b}} \pm 0.57$ & $52.67^{\mathrm{a}} \pm 0.83$ \\
20 & $4.73^{\mathrm{b}} \pm 0.44$ & $17.04^{\mathrm{b}} \pm 0.36$ & $7.22^{\mathrm{b}, \mathrm{c}} \pm 0.42$ & $13.36^{\mathrm{d}} \pm 0.44$ & $57.49^{\mathrm{a}} \pm 0.88$ \\
25 & $4.14^{\mathrm{a}, \mathrm{b}} \pm 0.13$ & $17.72^{\mathrm{b}} \pm 0.41$ & $8.35^{\mathrm{c}} \pm 0.96$ & $15.40^{\mathrm{c}, \mathrm{d}} \pm 0.32$ & $54.40^{\mathrm{a}} \pm 3.07$ \\
30 & $5.46^{\mathrm{b}} \pm 0.42$ & $15.21^{\mathrm{a}, \mathrm{b}} \pm 0.65$ & $8.41^{\mathrm{c}} \pm 0.11$ & $15.83^{\mathrm{c}, \mathrm{d}} \pm 0.27$ & $55.04^{\mathrm{a}} \pm 2.12$ \\
\hline
\end{tabular}

Calculated on dry matter basis. Determinations were performed in triplicate

Different letters within the same column indicate significant differences $(P<0.05)$

*Data presented as mean \pm standard deviation of triplicates

Table 3 Approximate composition (\%) of mango waste substrate inoculated with L. ramosa over 30 days

\begin{tabular}{lrrrrr}
\hline Time (days) & \multicolumn{1}{l}{ Lipids* } & \multicolumn{1}{l}{ Proteins* } & \multicolumn{1}{l}{ Ash* } & \multicolumn{1}{l}{ Fiber* } \\
\hline 0 & $0.52^{\mathrm{a}} \pm 0.56$ & $3.42^{\mathrm{a}} \pm 0.97$ & $2.25^{\mathrm{a}} \pm 0.26$ & $13.91^{\mathrm{a}, \mathrm{b}} \pm 0.86$ & $79.87^{\mathrm{a}} \pm 0.03$ \\
5 & $0.65^{\mathrm{a}} \pm 0.38$ & $7.75^{\mathrm{a}, \mathrm{b}, \mathrm{c}} \pm 0.28$ & $2.84^{\mathrm{a}, \mathrm{b}} \pm 0.08$ & $13.57^{\mathrm{a}} \pm 0.55$ & $75.40^{\mathrm{a}, \mathrm{b}} \pm 1.63$ \\
10 & $2.04^{\mathrm{a}, \mathrm{b}} \pm 0.15$ & $6.69^{\mathrm{a}, \mathrm{b}} \pm 0.19$ & $4.62^{\mathrm{a}, \mathrm{b}} \pm 0.60$ & $28.74^{\mathrm{d}} \pm 0.23$ & $58.11^{\mathrm{c}, \mathrm{d}} \pm 3.57$ \\
15 & $3.01^{\mathrm{a}, \mathrm{b}} \pm 0.74$ & $8.63^{\mathrm{b}, \mathrm{c}, \mathrm{d}} \pm 0.44$ & $5.07^{\mathrm{a}, \mathrm{b}} \pm 0.27$ & $20.57^{\mathrm{b}, \mathrm{c}} \pm 0.43$ & $62.75^{\mathrm{b}, \mathrm{c}} \pm 2.53$ \\
20 & $3.91^{\mathrm{b}} \pm 0.18$ & $11.31^{\mathrm{c}, \mathrm{d}} \pm 0.27$ & $3.73^{\mathrm{a}, \mathrm{b}} \pm 0.58$ & $27.44^{\mathrm{d}} \pm 0.18$ & $53.43^{\mathrm{c}, \mathrm{d}} \pm 0.61$ \\
25 & $4.53^{\mathrm{b}} \pm 0.04$ & $11.80^{\mathrm{c}, \mathrm{d}} \pm 0.62$ & $4.78^{\mathrm{a}, \mathrm{b}} \pm 0.17$ & $28.98^{\mathrm{d}} \pm 0.13$ & $47.96^{\mathrm{d}} \pm 3.45$ \\
30 & $3.97^{\mathrm{b}} \pm 0.49$ & $12.43^{\mathrm{d}} \pm 0.69$ & $5.75^{\mathrm{b}} \pm 0.52$ & $25.78^{\mathrm{c}, \mathrm{d}} \pm 0.20$ & $52.46^{\mathrm{c}, \mathrm{d}} \pm 3.52$ \\
\hline
\end{tabular}

Calculated on dry matter basis. Determinations were performed in triplicate

Different letters within the same column indicate significant differences $(P<0.05)$

*Data presented as mean \pm standard deviation of triplicates 
Table 4 Approximate composition (\%) of passion fruit waste substrate inoculated with L. ramosa over 30 days

\begin{tabular}{lrrlrr}
\hline Time (days) & \multicolumn{1}{l}{ Lipids $^{*}$} & \multicolumn{1}{l}{ Proteins* } & \multicolumn{1}{l}{ Ash* } & \multicolumn{1}{l}{ Fiber $^{*}$} & Carbohydrates* $^{*}$ \\
\hline 0 & $2.55^{\mathrm{a}, \mathrm{c}} \pm 0.62$ & $5.97^{\mathrm{a}} \pm 0.01$ & $3.34^{\mathrm{a}} \pm 0.10$ & $33.11^{\mathrm{a}, \mathrm{b}, \mathrm{c}} \pm 0.24$ & $55.01^{\mathrm{a}} \pm 0.80$ \\
5 & $1.82^{\mathrm{a}, \mathrm{b}} \pm 0.01$ & $8.73^{\mathrm{a}, \mathrm{b}} \pm 0.76$ & $9.15^{\mathrm{a}} \pm 0.41$ & $22.42^{\mathrm{a}, \mathrm{d}} \pm 0.19$ & $56.51^{\mathrm{a}} \pm 3.48$ \\
10 & $2.92^{\mathrm{a}, \mathrm{c}} \pm 0.83$ & $12.57^{\mathrm{b}, \mathrm{c}} \pm 0.34$ & $7.19^{\mathrm{a}} \pm 0.20$ & $21.32^{\mathrm{d}} \pm 0.53$ & $55.98^{\mathrm{a}} \pm 2.98$ \\
15 & $1.21^{\mathrm{b}} \pm 0.14$ & $24.45^{\mathrm{e}} \pm 0.89$ & $6.49^{\mathrm{a}} \pm 0.45$ & $28.54^{\mathrm{a}, \mathrm{b}, \mathrm{d}} \pm 0.17$ & $39.57^{\mathrm{b}} \pm 2.41$ \\
20 & $5.22^{\mathrm{e}} \pm 0.15$ & $16.78^{\mathrm{c}, \mathrm{d}} \pm 0.03$ & $9.08^{\mathrm{a}} \pm 0.74$ & $40.29^{\mathrm{b}, \mathrm{c}} \pm 0.22$ & $29.01^{\mathrm{b}, \mathrm{c}} \pm 1.69$ \\
25 & $3.72^{\mathrm{c}, \mathrm{d}} \pm 0.50$ & $17.68^{\mathrm{d}} \pm 0.04$ & $7.99^{\mathrm{a}} \pm 0.03$ & $38.99^{\mathrm{b}, \mathrm{c}} \pm 0.94$ & $32.00^{\mathrm{b}, \mathrm{c}} \pm 0.39$ \\
30 & $4.35^{\mathrm{d}, \mathrm{e}} \pm 0.04$ & $18.70^{\mathrm{d}} \pm 0.18$ & $8.38^{\mathrm{a}} \pm 0.11$ & $40.42^{\mathrm{c}} \pm 0.01$ & $27.72^{\mathrm{c}} \pm 3.08$ \\
\hline
\end{tabular}

Calculated on dry matter basis. Determinations were performed in triplicate Different letters within the same column indicate significant differences $(P<0.05)$

*Data presented as mean \pm standard deviation of triplicates

\begin{tabular}{lrrrrr}
\hline Time (days) & \multicolumn{1}{l}{ Lipids* } & \multicolumn{1}{l}{ Proteins* } & \multicolumn{1}{l}{ Ash* } & \multicolumn{1}{l}{ Fiber* } & Carbohydrates* \\
\hline 0 & $3.19^{\mathrm{a}} \pm 0.71$ & $14.55^{\mathrm{a}, \mathrm{b}} \pm 0.67$ & $3.29^{\mathrm{a}, \mathrm{b}} \pm 0.31$ & $54.09^{\mathrm{a}} \pm 0.63$ & $24.85^{\mathrm{a}} \pm 1.66$ \\
5 & $5.18^{\mathrm{a}} \pm 0.50$ & $14.84^{\mathrm{a}, \mathrm{b}} \pm 0.13$ & $4.06^{\mathrm{a}, \mathrm{b}} \pm 0.10$ & $57.32^{\mathrm{a}, \mathrm{b}} \pm 0.41$ & $19.11^{\mathrm{a}, \mathrm{b}} \pm 0.76$ \\
10 & $3.80^{\mathrm{a}} \pm 0.11$ & $16.89^{\mathrm{b}, \mathrm{c}} \pm 0.89$ & $2.77^{\mathrm{a}} \pm 0.02$ & $58.45^{\mathrm{a}, \mathrm{b}} \pm 0.06$ & $18.07^{\mathrm{a}, \mathrm{b}} \pm 0.34$ \\
15 & $4.76^{\mathrm{a}} \pm 0.40$ & $13.27^{\mathrm{a}} \pm 0.25$ & $4.31^{\mathrm{a}, \mathrm{b}} \pm 0.03$ & $66.31^{\mathrm{a}, \mathrm{b}} \pm 0.46$ & $11.35^{\mathrm{a}, \mathrm{b}} \pm 0.64$ \\
20 & $4.97^{\mathrm{a}} \pm 0.22$ & $13.57^{\mathrm{a}} \pm 0.79$ & $4.08^{\mathrm{a}, \mathrm{b}} \pm 0.05$ & $68.58^{\mathrm{b}} \pm 0.50$ & $8.95^{\mathrm{b}} \pm 0.70$ \\
25 & $4.57^{\mathrm{a}} \pm 0.47$ & $17.34^{\mathrm{c}} \pm 0.29$ & $3.99^{\mathrm{a}, \mathrm{b}} \pm 0.38$ & $63.80^{\mathrm{a}, \mathrm{b}} \pm 0.54$ & $10.14^{\mathrm{b}} \pm 1.05$ \\
30 & $2.97^{\mathrm{a}} \pm 0.25$ & $13.30^{\mathrm{a}} \pm 0.54$ & $4.84^{\mathrm{b}} \pm 0.50$ & $68.20^{\mathrm{b}} \pm 0.53$ & $9.96^{\mathrm{b}} \pm 0.01$ \\
\hline
\end{tabular}

Calculated on dry matter basis. Determinations were performed in triplicate

Different letters within the same column indicate significant differences $(P<0.05)$

*Data presented as mean \pm standard deviation of triplicates
Table 6 Protein enrichment after L. ramosa cultivations in pineapple, orange, mango, passion fruit and grape wastes substrates

\begin{tabular}{ll}
\hline Substrate & $\begin{array}{l}\text { Protein } \\
\text { enrichment } \\
(\%)\end{array}$ \\
\hline Pineapple waste & 294.89 \\
Orange waste & 65.60 \\
Mango waste & 263.45 \\
Passion fruit waste & 309.54 \\
Grape waste & 19.17 \\
\hline
\end{tabular}

Calculated from protein results of Tables 1, 2, 3, 4, 5 using Eq. 2

passion fruit (Table 4) and $14.55-17.34 \%$ in grape (Table 5) residues, showing significant difference for all cultivations $(P<0.05)$. Consequently, the protein enrichment was also found in all substrates (Table 6). It was higher for passion fruit (309.55\%), followed by pineapple (294.89\%), mango (263.45\%), orange $(65.60 \%)$ and grape $(19.17 \%)$ fruit wastes.

The literature reports protein enrichments of $29.59 \%$ and $31.72 \%$ in orange residues cultured for four days with $A$. niger and 5 days with Chaetomium spp., respectively [31]. The enrichment values are $30.31 \%$ and $37.20 \%$ in pequi and guavira residues, respectively, cultured for
30 days with $P$. sajor-caju [9]. Here also are the enrichments after 35 days for hog plum (391.66\%), araticum (143.31\%), and guavira (102.42\%). Finally, here are the enrichment values after 30 days for pequi (160.04\%) and bocaiuva (67.88\%) [1].

The lower protein enrichment observed for grape residue $(19.17 \%$ as shown in Table 6$)$ may be related to its lower initial carbohydrate content (24.85\%) and higher initial fiber content (54.09\%) as shown in Table 5. Carbohydrates are biomolecules that enable easier catabolism by the cells, especially if they contain residual sugars in their compositions. Therefore, it is expected to result in a higher biotransformation of proteins, or protein enrichment, during microbial growth [32]. In addition, grape skin residue is richer in the carbohydrate pectin [33], so it can be inferred that $L$. ramosa presents a reduced pectinolytic activity compared to other carbohydrates.

Despite the high carbohydrate content in orange residue $(63.06 \%$ as shown in Table 2$)$, its consumption was low, reaching a final concentration of $55.04 \%$, showed no significant difference $(P<0.05)$. In this case it is possible that the difficulty for the consumption of the carbohydrates from orange skin by L. ramosa may be related to the characteristic of the cell wall of this residue, which is rich in lignin [27]. 
The lipid content increased until the 20th day, decreasing after this period in pineapple and grape residues (Tables 1,5$)$, being statistically significant $(P<0.05)$. In mango waste, the increase occurred until the 25th day (Table 3), presenting statistical significance $(P<0.05)$, while in orange waste it was up to the 10th day (1.21-6.48\%), with statistical difference $(P>0.05)$, as shown in Table 2 .

When pequi and guavira wastes were cultivated with $P$. sajor-caju, they also showed an increase and subsequent decrease in lipid content [9]. The same happened with these substrates when cultured with L. ramosa [1]. This decrease in the lipid content can be related to the use of them in the synthesis of phospholipids, constituents of the cell membrane of fungi [34].

Regarding the ash content, this increased in all substrates (Tables 1, 2, 3, 4, 5), however with significant difference only in the pineapple, orange and mango residues $(P<0.05)$. This increase was less expressive in grape skin wastes (Table 5). Fiber content also increased, except for orange residue (Table 2), where there was no significant difference $(P>0.05)$.

\subsection{Enzymatic activity}

Figures 2, 3 and 4 present the enzymatic activities for amylase, CMCase, and xylanase, respectively, in the substrates comprised of pineapple, orange, mango, passion fruit and grape wastes, cultivated with L. ramosa for 30 days. Despite observed variation in lipid content, lipase activity was not detected in any of the cultivated media.

Amylase activity was observed in all substrates, except in cultivated grape waste. With pineapple waste, the production was of $5 \mathrm{U} / \mathrm{g}$ dry substrate (or $0.5 \mathrm{U} / \mathrm{mL}$ ) from the

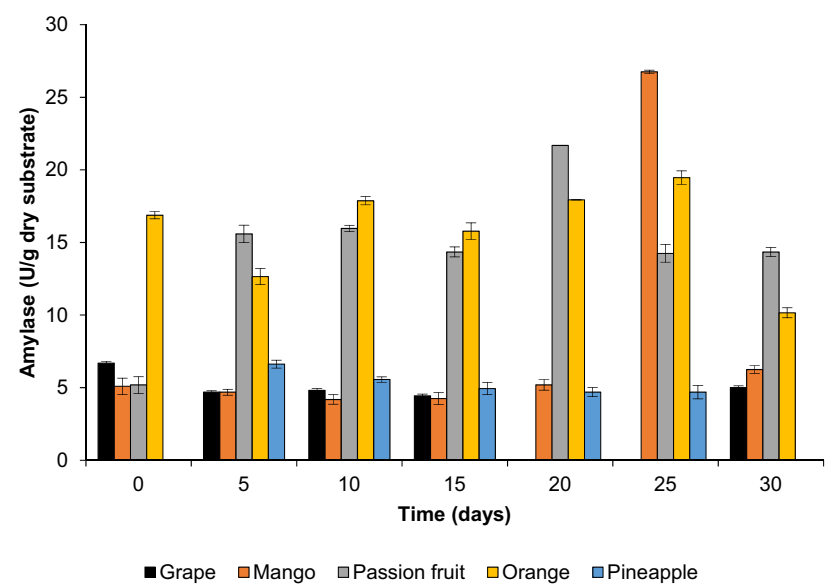

Fig. 2 Enzyme activity of amylase in pineapple, orange, passion fruit, mango and grape waste substrates cultivated with $L$. ramosa in function of the cultivation time. Analyzes were performed in triplicate

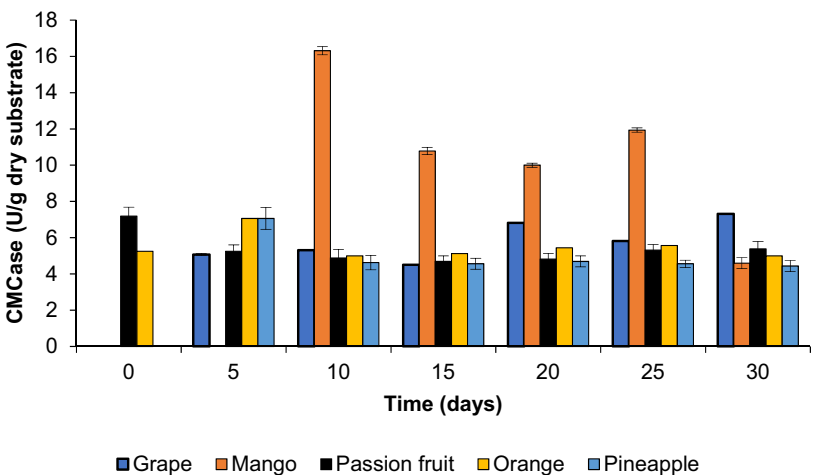

Fig. 3 Enzyme activity of CMCase in pineapple, orange, passion fruit, mango and grape waste substrates cultivated with $L$. ramosa in function of the cultivation time. Analyzes were performed in triplicate

5th day until the 25th day of cultivation. In orange residue there was no significant activity, but a stable content of $12-17 \mathrm{U} / \mathrm{g}$ dry substrate (or $1.2-1.7 \mathrm{U} / \mathrm{mL}$ ) throughout the process. The most significant activities were presented in the substrates comprised of mango and passion fruit wastes. With mango waste there was a maximal activity of $26.75 \mathrm{U} / \mathrm{g}$ dry substrate (or $2.675 \mathrm{U} / \mathrm{mL}$ ) on the 25 th day and with passion fruit the maximum content was of $21.69 \mathrm{U} / \mathrm{g}$ dry substrate (or $2.169 \mathrm{U} / \mathrm{mL}$ ) on the 20th day of cultivation, as shown in Fig. 2.

Amylase activities of $0.045,0.05,0.06$ and $0.08 \mathrm{U} / \mathrm{mL}$ were reported for rice husk, banana peels, vegetable waste (potato, tomato, eggplant) and wheat bran, respectively, with A. niger [35] and $9.4 \mathrm{U} / \mathrm{g}$ dry substrate for pequi residues with P. sajor-caju at the 20th day of cultivation [9]. Studies with bocaiuva, guavira and pequi residues showed maximum amylase activities of $1.80,1.09$ and $0.21 \mathrm{U} / \mathrm{mL}$, respectively, with L. ramosa [13].

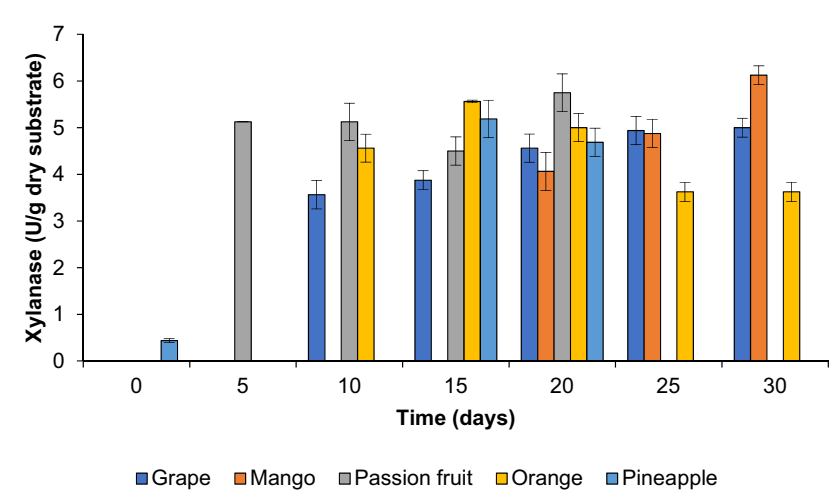

Fig. 4 Enzyme activity of xylanase in pineapple (open square), orange (filled circle), passion fruit (open circle), mango (open diamond) and grape (filled square) waste substrates cultivated with L. ramosa in function of the cultivation time. Analyzes were performed in triplicate 
CMCase activity was observed in all evaluated fruit wastes, mainly with mango residue, where a production of $16.31 \mathrm{U} / \mathrm{g}$ dry substrate (or $1.631 \mathrm{U} / \mathrm{mL}$ ) was reached at the 10th day of cultivation. This was followed by a production of around $5 \mathrm{U} / \mathrm{g}$ dry substrate (or $0.5 \mathrm{U} / \mathrm{mL}$ ) from the 5 th day of cultivation for grape and pineapple residues as shown in Fig. 3. Literature reports CMCase activities of $0.58,0.78$ and $0.64 \mathrm{U} / \mathrm{mL}$ when L. ramosa was cultured with bocaiuva, guavira and pequi residues, respectively [13].

All substrates presented xylanase activity. Pineapple residue showed $5 \mathrm{U} / \mathrm{g}$ dry substrate (or $0.5 \mathrm{U} / \mathrm{mL}$ ) between 15 and 20 days of cultivation while orange waste went from 4.5 to $5.5 \mathrm{U} / \mathrm{g}$ dry substrate (or 0.45 to $0.55 \mathrm{U} / \mathrm{mL}$ ) between 10 and 20 days. Passion fruit increased from 4.5 to $6.0 \mathrm{U} / \mathrm{g}$ between 5 and 20 days. In mango waste, the production was evident only at the 20th day $(4 \mathrm{U} / \mathrm{g}$ dry substrate) and maximal at 30 th day ( $6 \mathrm{U} / \mathrm{g}$ dry substrate). For grape residue the production was observed from the 10th day $(3.5 \mathrm{U} / \mathrm{g})$ and maximal from the 20th day $(6 \mathrm{U} / \mathrm{g})$, as shown in Fig. 4.

Activities of 4 and $8 \mathrm{U} / \mathrm{mL}$ were obtained for CMCase and xylanase, respectively, from Thermoascus aurantiacus, using fresh orange pulp as the substrate [36]. CMCase activities in the range of 3-4 $\mathrm{U} / \mathrm{g}$ dry substrate were found with pequi and guavira waste substrates and xylanase activity of $4.67 \mathrm{U} / \mathrm{g}$ with guavira waste substrate, using $P$. sajor-caju $[9,13]$. Productions of $0.82,0.63$ and $0.68 \mathrm{U} / \mathrm{mL}$ of xylanase were reported for bocaiuva, pequi and guavira residues, respectively, with $L$. ramosa [13].

In most of the evaluated substrates it is possible to verify a reduction of the enzymatic activity. This is likely explained by the consumption of the culture medium nutrients and the excretion of by-products by the microorganism used for fermentation. Such by-products, which may interfere with protein synthesis as well as enzymatic activity, include proteases and substances that reduce macro and micronutrients, alter the $\mathrm{pH}$, and decrease water availability $[2,5]$.
Despite the low concentration of enzymes produced, L. ramosa has potential for amylase, CMCase and xylanase enzyme production.

\subsection{Fatty acids}

Table 7 presents the fatty acid profile for passion fruit, grape, pineapple, orange and mango wastes at baseline (day 0 ) and end of cultivation (day 30) with L. ramosa.

$A$ variation in the fatty acid composition can be noted for non-inoculated substrates at day 0 to substrates cultivated for 30 days. Passion fruit waste substrates presented only palmitic acid but after 30 days cultivated with $L$. ramosa, composition varied for palmitic (31.04\%), linoleic $(41.88 \%)$ and oleic acids (27.08\%). In the grape waste substrate, the fatty acid composition included lauric (8.92\%), palmitic $(24.05 \%)$, linoleic $(23.51 \%)$, oleic $(33.58 \%)$ and stearic acids $(9.94 \%)$, while after 30 days of cultivation with L. ramosa, it was composed by palmitic (30.04\%), linoleic (23.28\%), oleic $(34.89 \%)$ and stearic acids $(11.78 \%)$. Pineapple waste substrate started with lauric (15.97\%), palmitic (33.24\%), oleic (36.24\%) and stearic acids (14.54\%) and ended with palmitic $(47.70 \%)$, oleic $(30.31 \%)$ and stearic acids (21.98\%). Orange waste substrate presented initial time palmitic (27.78\%), oleic (55.75\%) and stearic acid $(16.47 \%)$, whereas for the final time, palmitic acid $(48.79 \%)$ and oleic $(51.21 \%)$. Finally, the mango waste substrate, that presented only palmitic acid (100\%) at day 0 , had its composition changed to palmitic (37.64\%), linoleic $(5.64 \%)$, oleic $(32.49 \%)$ and stearic acids $(24.23 \%)$ as shown in Table 7.

With passion fruit, grape and mango waste substrates there was a conversion of saturated fatty acids to unsaturated, while the opposite occurred for the pineapple and orange waste substrates (Table 7). One possibility to explain the reduction in the unsaturated fatty acid content after cultivation is that lipolytic enzymes present in the substrate are breaking the double bonds in the
Table 7 Fatty acid composition (\%) for passion fruit, grape, pineapple, orange and mango waste substrates at initial time (day 0 ) and final time (30 days) cultivated with L. ramosa

\begin{tabular}{lllllllllll}
\hline Fatty acid & $\operatorname{Pas}_{(\mathrm{i})}$ & $\operatorname{Pas}_{(\mathrm{f})}$ & $\mathrm{Gra}_{(\mathrm{i})}$ & $\mathrm{Gra}_{(\mathrm{f})}$ & $\operatorname{Pin}_{(\mathrm{i})}$ & $\operatorname{Pin}_{(\mathrm{f})}$ & $\operatorname{Ora}_{(\mathrm{i})}$ & $\operatorname{Ora}_{(\mathrm{f})}$ & $\operatorname{Man}_{(\mathrm{i})}$ & $\operatorname{Man}_{(\mathrm{f})}$ \\
\hline Lauric acid (C12:0) & 100.00 & nd & 8.92 & nd & 15.97 & nd & nd & nd & nd & nd \\
Palmitic acid (C16:0) & nd & 31.04 & 24.05 & 30.04 & 33.24 & 47.70 & 27.78 & 48.79 & 100.00 & 37.64 \\
Linoleic acid (C18:2 (9,12)) & nd & 41.88 & 23.51 & 23.28 & nd & nd & nd & nd & nd & 5.64 \\
Oleic acid (C18:1 (n9)) & nd & 27.08 & 33.58 & 34.89 & 36.24 & 30.31 & 55.75 & 51.21 & nd & 32.49 \\
Estearic acid (C18:0) & nd & nd & 9.94 & 11.78 & 14.54 & 21.98 & 16.47 & nd & nd & 24.23 \\
I Saturated & 100.00 & 31.04 & 42.90 & 41.83 & 63.76 & 69.69 & 44.25 & 48.79 & 100.00 & 61.87 \\
I Unsaturated & - & 68.96 & 57.10 & 58.17 & 36.24 & 30.31 & 55.75 & 51.21 & - & 38.13 \\
\hline
\end{tabular}

Data presented in percentage

Pas, passion fruit; Pin, Pineapple; Ora, Orange; Man, Mango; nd, not detected; (i), initial; (f), final. Analyzes were performed in triplicate 
unsaturated fatty acids and turning them into saturated fatty acids [37].

In general, it was possible to observe a tendency to increase the size of the chains of saturated fatty acids, except for the cultures with the orange waste substrate, in which there was a shortening of the chain size from 18 to 16 carbons, whereas in the in other cases there was an increase in the chain from 12 or 16 to 18 carbons, with or without unsaturation (Table 7). The process of shortening the lipidic carbon chain is called $\beta$-oxidation of fatty acids, while the elongation process is called biosynthesis. Thus, it is possible to infer that in addition to the enzymatic complexes for carrying out the $\beta$-oxidation and fatty acid biosynthesis processes, the microorganism $L$. ramosa synthesizes the desaturase enzyme, responsible for the conversion of saturated to (poly)unsaturated fatty acids.

Finally, it is important to underline that different complex substrates with different compositions will induce distinct responses in the sense of inducing and/or repressing enzyme production. Different works in the literature using agro-industrial residues report these distinct behaviors depending on the composition and complexity of the media, not only for $L$. ramosa $[1,2,4,5,13,14]$, but also for other filamentous fungi species and strains cultivated in residues $[5,9-11,21]$.

\section{Conclusion}

Residues of pineapple fruit, orange, mango, passion fruit and grape were successfully used to the development of L. ramosa during SSB cultivations. Due to the complexity of the substrates utilized (fruit residues) it was difficult to make a correlation between microbial growth, enzymatic activity, and media composition (including fatty acids) especially if considered the heterogeneity of the substrates used. Protein enrichment was observed in all waste substrates; however, the utmost value was found for the passion fruit (309.54\%). The production of enzymes amylase, xylanase and CMCase was observed along with fatty acids, especially palmitic, oleic and stearic acids. These materials may be directly utilized as bio-transformed feed supplements for animal nutrition, produced at low costs, as it is not necessary to purify or concentrate them. However, it would be also important to carry out further studies in order to optimize the production of specific products detected here for different applications.

\section{Compliance with ethical standards}

Conflict of interest The authors declare that there are no conflict of interest.

\section{References}

1. Silva CAA, Lacerda MPF, Leite RSR, Fonseca GG (2014) Physiology of Lichtheimia ramosa obtained by solid-state bioprocess using fruit wastes as substrate. Bioproc Biosyst Eng 37:727-734. https ://doi.org/10.1007/s00449-013-1043-y

2. Garcia NFL, Santos FRS, Gonçalves FA, Da Paz MF, Fonseca GG, Leite RSR (2015) Production of $\beta$-glucosidase on solidstate fermentation by Lichtheimia ramosa in agroindustrial residues: Characterization and catalytic properties of the enzymatic extract. Electron J Biotechnol 18:314-319. https://doi. org/10.1016/j.ejbt.2015.05.007

3. Manan MA, Webb C (2017) Design aspects of solid state fermentation as applied to microbial bioprocessing. J Appl Biotechnol Bioeng 4:511-532. https://doi.org/10.15406/jabb.2017.04.00094

4. Silva PGP, Silva GFA, Dantas DP, Fonseca GG, Silva CAA (2014) Aproveitamento de resíduos de abacaxi (Ananas comosus) via bioprocesso em estado sólido com o fungo Lichtheimia ramosa. Magistra 26:198-202

5. Oliveira APA, Silvestre MA, Garcia NFL, Alves-Prado HF, Rodrigues A, Paz MF, Fonseca GG, Leite RSR (2016) Production and catalytic properties of amylases from Lichtheimia ramosa and Thermoascus aurantiacus by solid-state fermentation. Sci World J 2016:1-10. https://doi.org/10.1155/2016/7323875

6. Stabnikova O, Wang J, Ding HB, Tay J (2005) Biotransformation of vegetable and fruit processing wastes into yeast biomass enriched with selenium. Bioresour Technol 96:747-751. https ://doi.org/10.1016/j.biortech.2004.06.022

7. Shojaosadati SA, Babaripour V (2002) Citric acid production from apple pomace in multi-layer packed bed solid state bioreactor. Proc Biochem 37:909-914. https://doi.org/10.1016/S0032 -9592(01)00294-1

8. Kumar DV, Jain K, Shanker G, Srivastava A (2003) Utilization of fruits waste for citric acid production by solid state fermentation. Process Biochem 38:1725-1729. https://doi.org/10.1016/ S0032-9592(02)00253-4

9. Silva CAA, Lacerda MPF, Fonseca GG (2013) Biotransformation of pequi and guavira fruit wastes via solid state bioprocess using Pleurotus sajor-caju. Int J Biosci Biochem Bioinf 3:88-92. https:// doi.org/10.7763/IJBBB.2013.V3.171

10. Fonseca GG, Gandra EA, Sclowitz LF, Antunes APC, Costa JAV (2009) Protein enrichment and digestibility of soft rush (Juncus effusus) and rice residues using edible mushrooms Pleurotus ostreatus and Pleurotus sajor-caju. World J Microbiol Biotechnol 25:449-456. https://doi.org/10.1007/s11274-008-9909-x

11. de Morais TP, Barbosa PMG, Garcia NFL, da Rosa-Garzon NG, Fonseca GG, da Paz MF, Cabral H, Leite RSR (2018) Catalytic and thermodynamic properties of $\beta$-glucosidases produced by Lichtheimia corymbifera and Byssochlamys spectabilis. Prep Biochem Biotechnol. https://doi.org/10.1080/10826068.2018.1509083

12. Alastruey-Izquierdo A, Hoffmann K, Hoog GS, Rodriguez-Tudela JL, Voigt K, Bibashi E, Walther G (2010) Species recognition and clinical relevance of the zygomycetous genus Lichtheimia (syn. Mycocladus, Absidia pp.). J Clin Microbiol 48:2154-2170. https ://doi.org/10.1128/JCM.01744-09

13. Silva CAA, Lacerda MPL, Leite RSR, Fonseca GG (2013) Production of enzymes from Lichtheimia ramosa using Brazilian savannah fruit wastes as substrate on solid state bioprocesses. Electron J Biotechnol 16:1-9. https://doi.org/10.2225/vol16-issue 5-fulltext-7

14. Gonçalves FA, Leite RSR, Rodrigues A, Sanjinez-Argandoña EJ, Fonseca GG (2013) Isolation, identification and characterization of a novel high level $\beta$-glucosidase producing Lichtheimia ramosa strain. Biocatal Agric Biotechnol 2:377-384. https://doi. org/10.1016/j.bcab.2013.06.006 
15. Lynch GP, Jacoby NM, Benjamin CR, Shalkop WT, Chance CM (1970) Feeding high moisture, ensiled, moldy shelled corn. J Dairy Sci 53:1292-31295. https://doi.org/10.3168/jds.S0022 $-0302(70) 86385-8$

16. International Commission on Microbiological Specifications for Foods (ICMSF) (1978) Microorganisms in foods: their significance and methods of enumeration. University of Toronto Press, Toronto

17. International Commission on Microbiological Specifications for Foods (ICMSF) (1986) Microorganisms in foods. Sampling for microbiological analysis: principles and scientific applications, vol 2. University of Toronto Press, Toronto

18. Nascimento VM, Silva LF, Gomez JGC, Fonseca GG (2016) Growth of Burkholderia sacchari LFM 101 cultivated in glucose, sucrose and glycerol. Sci Agric 73:429-433. https://doi. org/10.1590/0103-9016-2015-0196

19. Silva N, Junqueira VCA, Silveira NFA (1997) Manual de Métodos de Análise Microbiológica de Alimentos. Livraria Varela, Brasil, pp 45-60

20. Association of Official Analytical Chemists (AOAC) (2000) Official methods of analyses. Association of Official Analytical Chemists, Washington, DC

21. Leite RSR, Bocchini DA, Martins ES, Silva D, Gomes E, Silva R (2007) Production of cellulolytic and hemicellulolytic enzymes from Aureobasidium pulluans on solid state fermentation. Appl Biochem Biotechnol 137-140:281-288. https://doi.org/10.1007/ s12010-007-9058-y

22. Miller GL (1959) Use of dinitrosalicylic acid reagent for determination of reducing sugars. Anal Chem 31:426-428. https://doi. org/10.1021/ac60147a030

23. Liu Z, Zhenming C, Wang L, Jing L (2008) Production, purification and characterization of an extracellular lipase from Aureobasidium pullulans HN2.3 with potential application for the hydrolysis of edible oils. Biochem Eng J 40:445-451. https ://doi.org/10.1016/j.bej.2008.01.014

24. Bligh EG, Dyer WJ (1959) A rapid method of total lipid extraction and purification. Can J Biochem Physiol 37:911-917. https://doi. org/10.1139/059-099

25. AOCS (2004) Official methods and recommended practices of the American Oil Chemists' Society. AOCS Press, Champaign

26. Menegazzo ML, Petenuci ME, Fonseca GG (2014) Production and characterization of crude and refined oils obtained from the co-products of Nile tilapia and hybrid sorubim processing. Food Chem 157:100-104. https://doi.org/10.1016/j.foodc hem.2014.01.121

27. Colombatto D, Mould FL, Bhat MK (2003) Use of fibrolytic enzymes to improve the nutritive value of ruminant diets. A biochemical and in vitro rumen degradation assessment. Anim Feed Sci Technol 107:201-209. https://doi.org/10.1016/S0377 $-8401(03) 00126-3$
28. Negro V, Mancini G, Ruggeri B, Fino D (2016) Citrus waste as feedstock for bio-based products recovery: review on limonene case study and energy valorization. Bioresour Technol 214:806815. https://doi.org/10.1016/j.biortech.2016.05.006

29. Bakkali F, Averbeck S, Averbeck D, Idaomar M (2008) Biological effects of essential oils: review. Food Chem Toxicol 46:446-475. https://doi.org/10.1016/j.fct.2007.09.106

30. Ruiz HA, Rodríguez-Jasso RM, Rodríguez R, Contreras-Esquivel JC, Aguilar CN (2012) Pectinase production from lemon peel pomace as support and carbon source in solid-state fermentation column-tray bioreactor. Biochem Eng J 65:90-95. https:// doi.org/10.1016/j.bej.2012.03.007

31. Yalemtesfa B, Alemu T, Santhanam A (2010) Solid substrate fermentation and conversion of orange waste in to fungal biomass using Aspergillus niger KA-06 and Chaetomium Spp KC-06. Afr J Microbiol Res 4:1275-1281

32. Silveira CM, Badiale-Furlong E (2007) Characterization of nitrogenated compounds in solid state fermented bran. Ciên Tecnol Alimen 27:805-811. https://doi.org/10.1590/S0101-2061200700 0400021

33. Ortega-Regules A, Ros-García JM, Bautista-Ortín AB, López-Roca JM, Gómez-Plaza E (2008) Differences in morphology and composition of skin and pulp cell walls from grapes (Vitis vinifera L.): technological implications. Eur Food Res Technol 227:223-231. https://doi.org/10.1007/s00217-007-0714-9

34. Oliveira MS, Feddern V, Kupski L, Cipolatti EP, Badiale-Furlong E, Souza-Soares LA (2011) Changes in lipid, fatty acids and phospholipids composition of whole rice bran after solid-state fungal fermentation. Bioresour Technol 102:8335-8338. https://doi. org/10.1016/j.biortech.2011.06.025

35. Khan JA, Yadav SK (2011) Production of alpha amylases by Aspergillus niger using cheaper substrates employing solid state fermentation. Int J Plant Anim Environ Sci 1:100-108

36. Da Silva R, Lago ES, Merheb CW, Macchione MM, Park YK, Gomes E (2005) Production of xylanase and CMCase on solid state fermentation in different residues by Thermoascus aurantiacus miehe. Braz J Microbiol 36:235-241. https://doi.org/10.1590/ S1517-83822005000300006

37. Silveira CM, Oliveira MS, Badiale-Furlong E (2010) Conteúdo lipídico e perfil em ácidos graxos de farelos submetidos à fermentação por Aspergillus oryzae em estado sólido. Bol CEPPA 28:133-140. https://doi.org/10.5380/cep.v28i1.17904

Publisher's Note Springer Nature remains neutral with regard to jurisdictional claims in published maps and institutional affiliations. 